\title{
Memory and Spatial Cognition in Breast Cancer Patients Undergoing Adjuvant Endocrine Therapy
} \author{
Christoph Thomssen ${ }^{\text {a }}$ \\ a Department of Gynecology, Martin Luther University, Halle, Germany; \\ bInstitute of Psychology, Martin Luther University, Halle, Germany; \\ ${ }^{c}$ St. Elisabeth Hospital, Halle, Germany
}

Ute Berndt $^{\mathrm{a}}$ Bernd Leplow ${ }^{\mathrm{b}}$ Robby Schoenfeld ${ }^{\mathrm{b}} \quad$ Tilmann Lantzsch $^{\mathrm{c}}$ Regina Grosse $^{\mathrm{a}}$

\section{Keywords}

Breast cancer · Oncology · Tamoxifen .

Aromatase inhibitor · Memory · Spatial cognition

\section{Summary}

Introduction: It is generally accepted that estrogens play a protective role in cognitive function. Therefore, it can be expected that subtotal estrogen deprivation following aromatase inhibition will alter cognitive performance. Methods: In a cross-sectional study we investigated 80 postmenopausal women with breast cancer. Memory and spatial cognition were compared across 4 treatment groups: tamoxifen only (TAM, $n=22$ ), aromatase inhibitor only (AI, $n=22$ ), TAM followed by Al ('SWITCH group', $n=15$ ), and patients with local therapy (LT) only (surgery and radiation, $\mathrm{n}=21$ ). Duration of the 2 endocrine monotherapy arms prior to the assessment ranged from 1 to 3 years. The 'SWITCH group' received 2-3 years TAM followed by at least 1 year and at most 3 years of Al. Memory and spatial cognition were investigated as planned comparisons. Investigations of processing speed, attention, executive function, visuoconstruction and self-perception of memory were exploratory. Results: With regard to general memory, Al patients performed significantly worse than the LT group ( $p=0.013$ ). Significant differences in verbal memory did not remain significant after $p$-value correction for multiple testing. We found no significant differences concerning spatial cognition between the groups. Conclusion: Al treatment alone significantly impairs general memory compared to the LT group.

(c) 2016 S. Karger GmbH, Freiburg

\section{Introduction}

Adjuvant endocrine therapy substantially reduces recurrence rates and improves overall survival in women with hormone receptor-positive early breast cancer. However, in the clinical routine, numerous patients with breast cancer complain of memory and concentration problems.

Estrogen receptors have been documented in various parts of the brain [1]. Estrogens play an important role in the regulation of growth and differentiation of axons, dendrites and synapses [2], support long-term potentiation in the hippocampus [3,4] and influence serotonergic, noradrenergic, dopaminergic and cholinergic activities [5]. The glutamate system, which is involved in learning and memory, also is regulated by estrogens [6]. Estrogens also act as antioxidants $[4,7]$. Neuroprotective function has been demonstrated in lab animal studies, as the expression of aromatase is increased in the brain after injury [8]. Estrogens are also discussed as a target for therapeutic approaches in neurodegenerative and mental diseases [9].

A number of studies in animals and in humans show influences of sex hormones, especially estrogens, in memory and spatial cognition caused by changing of hormone levels during life span, menstrual cycle, pregnancy, menopause, hormone therapy or ovarectomy [10-14]. Therefore, in our study we focused mainly on these 2 domains.

The mechanism for endocrine therapy in patients with hormone receptor-positive breast cancer may be described as follows: tamoxifen (TAM) as an estrogen receptor (ER) modulator binds to ERs in competition with estradiol; thus, transcription is altered. Tumor cells are arrested in a non-proliferative state but, depending on the molecular profile of its target tissue, TAM may also act similarly to estradiol as an agonist [15]. AIs, however, work by inhibiting the activity of the aromatase, which is needed to convert androgens to estrogens [16]. Patients on AI are nearly completely deprived of estrogens.

\section{KARGER \\ Fax +497614520714

(c) 2016 S. Karger GmbH, Freiburg 


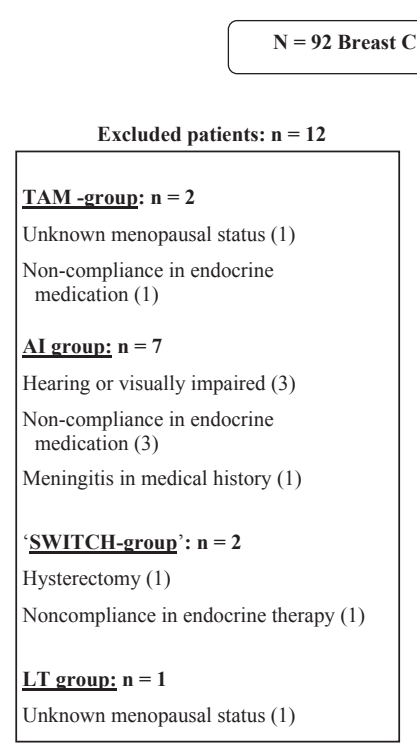

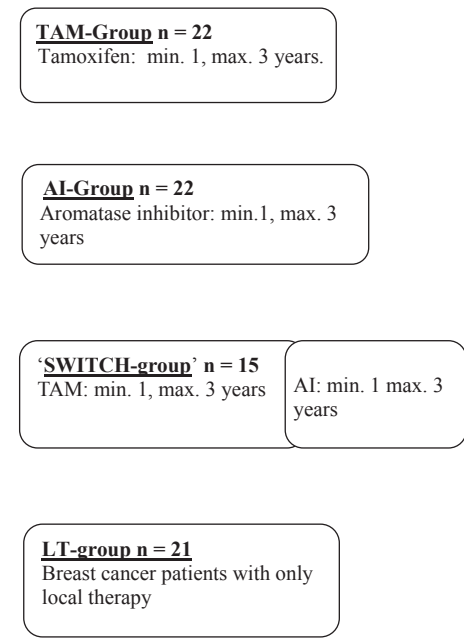

Fig. 1. Consort diagram.

Against the background of the neurophysiological findings concerning protective effects of estrogens, increasing interest has developed with regard to the cognitive effects of endocrine therapy especially with respect to the almost complete estrogen depletion caused by AIs. Preceding study results concerning profile, extent and duration of cognitive impairments in patients undergoing endocrine therapy are inconsistent [17]. In contrast to previous studies we assessed cognitive abilities in postmenopausal breast cancer patients undergoing differentiated endocrine protocols. The exclusion of premenopausal women and those who were treated with chemotherapy should avoid the impact of some known confounders. Since it is known that $17 \beta$-estradiol regulates hippocampal plasticity [9] as well as memory and spatial cognition [18], we assessed these domains. We wanted to confirm the hypothesis that a nearly complete estrogen deprivation by AI would affect memory and spatial cognition of these patients.

\section{Material and Methods}

\section{Participants}

A cross-sectional study was used to investigate 92 postmenopausal women with breast cancer recruited from 2 breast cancer centers. Patients were excluded for premenopausal status, organic brain diseases (even before cancer onset), a history of mental disorders (e.g. stroke, major depression, etc.), medication affecting the central nervous system (CNS), previous chemotherapy treatment and treatment with gonadotropin-releasing hormone $(\mathrm{GnRH})$ agonists (ovarian function suppression), below average IQ (IQ score less than 85), alcohol or drug abuse (present or past), any metastases, or age above 80 years. The age limit was defined to exclude age-related cognitive dysfunctions like dementia. To compare cognitive task performance we constituted 4 treatment groups in the context of a quasi-experimental design: We investigated patients undergoing therapy with TAM only $(n=22)$, AI only $(n=22)$, patients who 'switched' from TAM to an AI ('SWITCH group', $\mathrm{n}=15$ ) and breast cancer patients who had received only local therapy (LT) such as surgery or radiation $(\mathrm{n}=21)$ (see consort diagram, fig. 1).

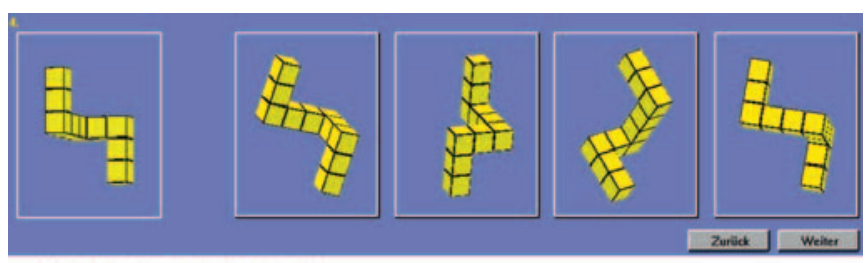

Mental Rotation Test
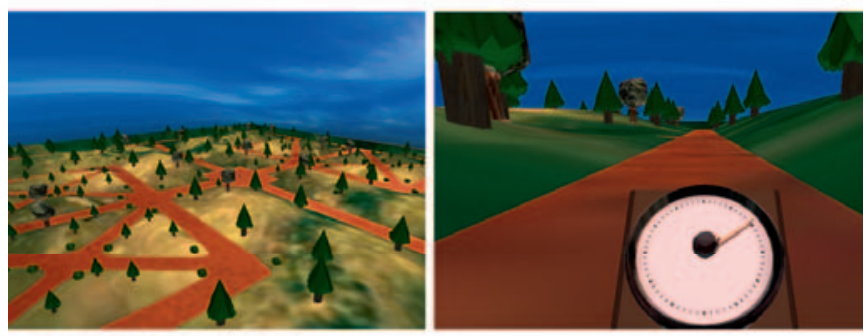

Virtual Pointing Task
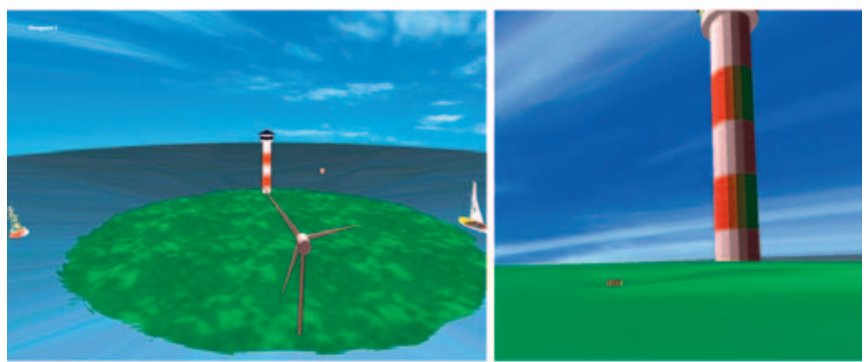

Object in Location Test

Fig. 2. Spatial cognition tests.

Assessment

Demographic data were obtained through standardized interviews and clinical data were gleaned from the electronic health record. Compliance with endocrine therapy was evaluated by interview. Only patients who reported a daily intake of the medication were included. Drug levels were not assessed.

Memory and spatial cognition (mental rotation, navigation: Virtual Pointing Task, Object in Location Test) were investigated as planned comparisons. Investigations of processing speed, attention, executive function, visuoconstruction and self-perception of memory were exploratory. We also assessed mood and premorbid intelligence to check potential confounding variables and to parallelize the groups. On an exploratory basis we were also interested in correlation between self-perception of memory and objective measures as well as self-perception, anxiety and depression.

As background measures, we used the following psychological tests: for selfperception of memory: the Memory Assessment Clinic Self-Report Scale [19]; for mood: the Mental State Scale [20] and the Hospital Anxiety and Depression Scale-D [21]; and for premorbid intelligence: the Multiple Choice Vocabulary Test [22].

\section{Assessment of Cognitive Performance}

Memory, spatial cognition, processing speed and attention were assessed using a battery of neuropsychological tests. The assessment took about $2 \mathrm{~h}$. Following instruments were used: for visual attention and task switching (processing speed, executive function): Trail Making-Test A and B [23]; for memory and visuoconstruction: Wechsler Memory Scale-R Part 1 [24], and Rey- Osterrieth Complex Figure Test (copy trial and delayed recall) [25]; and for spatial cognition: Mental Rotation Test [26], Virtual Pointing Task [27], and Object in Location Test $[27,28]$, see figure 2. All tests used to assess spatial cognition were performed on a personal computer (PC).

For the Mental Rotation Test [26], patients were required to judge whether 2 rotated abstract block figures were congruent or different. Each stimulus was 
Table 1. Characteristics of the patient sample

\begin{tabular}{|c|c|c|c|c|c|c|c|}
\hline Parameter & $\begin{array}{l}\mathrm{LT}, \\
\mathrm{n}=21\end{array}$ & $\begin{array}{l}\text { TAM, } \\
\mathrm{n}=22\end{array}$ & $\begin{array}{l}\text { AI, } \\
n=22\end{array}$ & $\begin{array}{l}\text { SWITCH, } \\
\mathrm{n}=15\end{array}$ & $\begin{array}{l}\text { Test } \\
\text { statistic }\end{array}$ & $\mathrm{p}$ & $\begin{array}{l}\text { Significant post } \\
\text { hoc comparisons }\end{array}$ \\
\hline Age, years, mean (SD) & $64.9(7.3)$ & $62.6(8.7)$ & $68.3(5.1)$ & $65.3(7.9)$ & $\mathrm{F}=2.1$ & 0.10 & \\
\hline Menopause, years, mean (SD) & $13.4(7.8)$ & $12.2(10)$ & $18.1(5.9)$ & $15.6(7.8)$ & $\mathrm{F}=2.24$ & 0.09 & \\
\hline \multicolumn{8}{|l|}{ Education, $\mathrm{n}(\%)^{\mathrm{a}}$} \\
\hline Secondary modern school & $9(42.8)$ & $10(45.5)$ & $13(59.1)$ & $9(60.0)$ & \multirow[t]{3}{*}{$x^{2}=2.97$} & \multirow[t]{3}{*}{0.81} & \\
\hline Intermediate school & $6(28.6)$ & $8(36.4)$ & $6(27.3)$ & $4(26.7)$ & & & \\
\hline Grammar school & $6(28.6)$ & $4(18.2)$ & $3(13.6)$ & $2(13.3)$ & & & \\
\hline \multicolumn{8}{|l|}{ Professional level, n (\%) } \\
\hline Untrained & $1(4.8)$ & $1(4.5)$ & $1(4.5)$ & $2(13.3)$ & \multirow[t]{4}{*}{$\chi^{2}=9.36$} & \multirow[t]{4}{*}{0.4} & \\
\hline Apprenticeship & $10(47.6)$ & $12(54.5)$ & $16(72.7)$ & $9(60.0)$ & & & \\
\hline College of higher education & $8(38.1)$ & $5(22.7)$ & $4(18.2)$ & $1(6.7)$ & & & \\
\hline University & $2(9.5)$ & $4(18.2)$ & $1(4.5)$ & $3(20.0)$ & & & \\
\hline \multicolumn{8}{|l|}{ Employment, n (\%) } \\
\hline Fulltime & $4(19.0)$ & $7(31.8)$ & 0 & $1(6.7)$ & \multirow[t]{3}{*}{$\chi^{2}=22.15$} & \multirow[t]{3}{*}{0.06} & \\
\hline Partime & $1(4.8)$ & $1(4.5)$ & 0 & 0 & & & \\
\hline Not employed & $16(76.2)$ & $14(63.6)$ & $22(100)$ & $14(93.3)$ & & & \\
\hline MSS t value, mean (SD) & $49.0(8.8)$ & $52.8(8.8)$ & $48.5(10.5)$ & $54.9(15.8)$ & $\mathrm{F}=1.47$ & 0.23 & \\
\hline Anxiety t value, mean (SD) & $53.5(10.3)$ & $55.0(11.6)$ & $50.2(11.9)$ & $56.3(14.2)$ & $\mathrm{F}=0.98$ & 0.41 & \\
\hline Depression $\mathrm{t}$ value, mean (SD) & $55.6(10.1)$ & $57.8(8.8)$ & $57.0(11.7)$ & $58.5(15.7)$ & $\mathrm{F}=0.23$ & 0.87 & \\
\hline Intelligence, IQ, mean (SD) & $115.4(14.7)$ & $112.3(15.0)$ & $112.6(13.0)$ & $114.6(17.2)$ & $\mathrm{F}=0.21$ & 0.88 & \\
\hline \multicolumn{8}{|l|}{ Family status, n (\%) } \\
\hline Married & $12(57.1)$ & $19(86.4)$ & $16(72.7)$ & $10(66.7)$ & \multirow[t]{4}{*}{$\chi^{2}=7.55$} & \multirow[t]{4}{*}{0.58} & \\
\hline Separated & $1(4.8)$ & 0 & 0 & $1(6.7)$ & & & \\
\hline Divorced & $3(14.3)$ & 0 & $2(9.1)$ & $1(6.7)$ & & & \\
\hline Widowed & $5(23.8)$ & $3(13.6)$ & $4(18.2)$ & $3(20.0)$ & & & \\
\hline HRT before BC, $\%$ & 28.6 & 27.3 & 18.2 & 73.3 & $\chi^{2}=13.56$ & $0.004^{* *}$ & SWITCH vs. all \\
\hline $\begin{array}{l}\text { Duration of treatment, } \\
\text { months, mean (SD)b }\end{array}$ & & $21.5(8.6)$ & $24.1(9)$ & & $\mathrm{t}=-1.2$ & 0.23 & \\
\hline $\begin{array}{l}\text { Time since diagnosis, } \\
\text { months, mean }(\mathrm{SD})^{\mathrm{b}}\end{array}$ & $<1$ & $23.2(9)$ & $26.9(10.1)$ & $>36-60$ & $\mathrm{t}=-1.28$ & 0.21 & \\
\hline $\begin{array}{l}\text { Duration of AI treatment, } \\
\text { months, mean }(\mathrm{SD})^{\mathrm{c}}\end{array}$ & & & $24.1(9)$ & $22.3(11)$ & $\mathrm{t}=0.53$ & 0.6 & \\
\hline
\end{tabular}

${ }^{a}$ German: secondary modern school = Hauptschule, intermediate school = Sekundarschule, grammar school = Gymnasium .

${ }^{\mathrm{b}}$ Only the monotherapy groups were compared.

${ }^{c}$ Only AI treatment times were compared.

MSS $=$ Mental State Scale, $\mathrm{LT}=$ local therapy, TAM $=$ tamoxifen, $\mathrm{AI}=$ aromatase inhibitor, $\mathrm{SWITCH}=\mathrm{TAM} \rightarrow \mathrm{AI}, \mathrm{BC}=$ breast cancer, $\mathrm{SD}=$ standard deviation,

HRT $=$ hormone replacement therapy, est. = estimated.

${ }^{*}$ Significant $\mathrm{p}<0.01$.

a 2-dimensional image of a 3-dimensional object and was then shown at different orientations rotated around the vertical axis. Patients had to rotate the figure in their mind to compare 4 response-choice figures to the target figure. They had to complete 2 runs within a time limit ( 10 min every run, 2 min break between the runs). We used 2 methods of scoring: 'lenient' in which every right answer counted; and 'strict' in which answers were only valid if both figures are identified correctly.

For the Virtual Pointing Task (navigation without landmarks) [27], patients 'walked' through a virtual park. They were instructed to remember the position of the starting point. Finally, they were requested to position the compass to the 'home' direction. This test was administered at 2 different speeds and 3 different levels of difficulty (a total of 6 runs).

For the Object in Location Test (navigation with landmarks adapted from an animal trial: the Morris Water Maze Experiment [28], the task involved the exploration of a virtual island. Patients were required to find a treasure chest. Landmarks on the island could be used as assistance. After this, they started again from different positions on the island. The position of the chest did not change.

\section{Statistical Analysis}

The data analysis was performed with the Statistical Package for the Social Sciences (SPSS), version 17.0. Performance differences between the groups were compared using ANOVA (analysis of variance). For parameters not following the normal distribution, the Kruskal-Wallis test as a non-parametric method was used. If a significant effect was detected by ANOVA, multiple comparison tests (post hoc tests, e.g. Bonferroni test) were used. In a case of statistically significant differences of the means, the effect size (Cohens d) was calculated. In addition, we used ANCOVA (analysis of covariance) to control age as a potential confounder (age as independent variable (covariate), memory as dependent variable, and the 4 treatment groups as fixed factors). The level of significance was established at 0.05, 2-tailed. Group differences of nominal data were calculated by the Chi ${ }^{2}$ test. Because of the multiple comparisons in our study we used the Benjamini-Hochberg correction [29] to reduce the number of false-positives results with a critical value for the false discovery rate of 0.2 . The Pearson product-moment correlation coefficient was calculated to assess the correlation of mood (values of anxiety, depression and mental state scale), self-reported cognitive func- 
Table 2. Self-perception of memory (exploratory)

\begin{tabular}{|c|c|c|c|c|c|c|c|}
\hline & $\begin{array}{l}\mathrm{LT} \\
\mathrm{n}=21\end{array}$ & $\begin{array}{l}\text { TAM, } \\
\mathrm{n}=22\end{array}$ & $\begin{array}{l}\mathrm{AI}, \\
\mathrm{n}=22\end{array}$ & $\begin{array}{l}\text { SWITCH, } \\
\mathrm{n}=15\end{array}$ & $\begin{array}{l}\text { Test } \\
\text { tatistic }\end{array}$ & (p) & $\begin{array}{l}\text { Significant } \\
\text { post hoc } \\
\text { comparisons }\end{array}$ \\
\hline \multicolumn{8}{|l|}{ Ability scale } \\
\hline $\begin{array}{l}\text { Personal long-term } \\
\text { memory, mean }(\mathrm{SD})^{\mathrm{a}}\end{array}$ & $3.7(0.5)$ & $3.6(0.6)$ & $3.5(0.47)$ & $3.6(0.7)$ & $\mathrm{F}=0.5$ & $(0.68)$ & \\
\hline $\begin{array}{l}\text { Memory of numbers, } \\
\text { mean (SD) }\end{array}$ & $3.1(0.9)$ & $3.2(0.7)$ & $3.4(0.6)$ & $3.3(0.6)$ & $\mathrm{F}=0.9$ & $(0.44)$ & \\
\hline $\begin{array}{l}\text { Memory for daily tasks, } \\
\text { mean (SD) }\end{array}$ & $3.9(0.6)$ & $3.4(0.6)$ & $3.6(0.5)$ & $3.9(0.6)$ & $\mathrm{F}=3.7$ & $\left(0.016^{*}\right)$ & $\begin{array}{l}\text { LT better } \\
\text { than TAM }\end{array}$ \\
\hline $\begin{array}{l}\text { Semantic memory/word } \\
\text { recall, mean (SD) }\end{array}$ & $3.3(0.6)$ & $3.2(0.6)$ & $3.4(0.6)$ & $3.4(0.6)$ & $\mathrm{F}=0.45$ & $(0.72)$ & \\
\hline $\begin{array}{l}\text { Topographic memory, } \\
\text { mean (SD) }\end{array}$ & $3.6(0.6)$ & $3.4(0.8)$ & $3.4(0.6)$ & $3.6(0.4)$ & $\mathrm{F}=0.8$ & $(0.49)$ & \\
\hline \multicolumn{8}{|l|}{ Frequency scale } \\
\hline $\begin{array}{l}\text { Attention/concentration, } \\
\text { mean }(\mathrm{SD})^{\mathrm{a}}\end{array}$ & $3.8(0.5)$ & $3.8(0.7)$ & $4.1(0.5)$ & $3.7(0.7)$ & $\mathrm{F}=0.11$ & $(0.49)$ & \\
\hline $\begin{array}{l}\text { Semantic memory for words } \\
\text { and facts, rank }{ }^{b}\end{array}$ & 46.7 & 34.3 & 43.9 & 35.7 & $\chi^{2}=4.3$ & $(0.23)$ & \\
\hline General forgetfulness, rank ${ }^{\mathrm{b}}$ & 47.7 & 41.9 & 51.6 & 12.17 & $x^{2}=31.1$ & $\left(0.000^{* *}\right)$ & $\begin{array}{l}\text { all better than } \\
\text { SWITCH }\end{array}$ \\
\hline
\end{tabular}

${ }^{\mathrm{a}}$ Mean of the 5-step rating scale: low values indicate the self-perception of high memory deficits.

bNo normal distribution.

$\mathrm{LT}=$ local therapy, TAM $=$ tamoxifen, $\mathrm{AI}=$ aromatase inhibitor, $\mathrm{SWITCH}=\mathrm{TAM} \rightarrow \mathrm{AI}, \mathrm{SD}=$ standard deviation.

${ }^{\star}$ Significance $\mathrm{p}<0.05,{ }^{* *}$ significance $\mathrm{p}<0.01$. tion (8 subscales) and test data (general memory, verbal memory and visual memory) of the sample as whole (all groups), assuming the data were normally distributed. Otherwise, the Spearman's rank correlation coefficient was used.

\section{Results}

The groups did not differ significantly with regard to demographic characteristics such as age, time since menopause, education, professional level, employment, mental state, anxiety, depression, intelligence and family status. Significantly more patients of the 'SWITCH group' had previously received hormone therapy (HT) for postmenopausal symptoms before diagnosis of breast cancer compared to all other groups $(\mathrm{p}=0.004)$ (table 1$)$. However, in most cases, HT was discontinued months to years prior to breast cancer diagnosis and the duration was highly heterogeneous (range 3-180 months). The 2 monotherapy groups (TAM and AI) did not show significant differences concerning the duration of HT. The same applied to time since diagnosis and duration of AI therapy in the groups AI and 'SWITCH group' (table 1).

Overall, the AI group showed more impaired abilities concerning verbal and general memory than the control group. However, after correction for multiple tests using the Benjamini-Hochberg method, only the value concerning general memory remained significant. Furthermore, we noticed some interesting results with regard to executive function, visuoconstruction and selfperception.

\section{Self-Perception of Memory (Exploratory)}

Most patients perceived their own memory performance as average. Self-perception of memory correlated negatively with anxiety and depression but not with the objective test data. Taking into count the fact that we have many correlation data, the results should be interpreted with caution. In terms of memory self-assessment, appreciable differences between the groups were found in these 2 domains. The 'SWITCH group' perceived a lower mean concerning forgetfulness than all the other groups. Lower values indicate the self-perception of higher memory deficits. The LT group had a better self-perception concerning their memory of daily tasks on the ability scale compared to the TAM group (table 2).

\section{Memory (Planned Comparisons)}

Women who solely received AI without any TAM treatment in the past showed a significant impairment of general memory in comparison to the LT group ( $\mathrm{p}=0.013, \mathrm{~d}=1.15$ large effect). Concerning verbal memory and visuoconstruction, the AI group performed worse than any other group ( $\mathrm{p}=0.037$, respectively) (see table 3). Adjusting for multiple comparisons, the differences did not remain significant. It is remarkable that many of the patients investigated showed below average memory performances compared with normative data of matched healthy women (scores less than 85 are below average). This applied particularly to the AI group. AI patients showed values below average for general memory $36.4 \%$, verbal memory $54.5 \%$ and attention $31.8 \%$. 
Table 3. Results for memory, visuoconstruction, attention and executive functioning

\begin{tabular}{|c|c|c|c|c|c|c|c|c|}
\hline Parameter & $\begin{array}{l}\mathrm{LT} \\
\mathrm{n}=21\end{array}$ & $\begin{array}{l}\text { TAM } \\
\mathrm{n}=22\end{array}$ & $\begin{array}{l}\text { AI } \\
n=22\end{array}$ & $\begin{array}{l}\text { SWITCH } \\
\mathrm{n}=15\end{array}$ & $\begin{array}{l}\text { Test } \\
\text { statistic }\end{array}$ & $\mathrm{p}$ & $\begin{array}{l}\text { Significant } \\
\text { post hoc } \\
\text { comparisons }\end{array}$ & Effect size \\
\hline Memory, mean $(\mathrm{SD})^{\mathrm{a}}$ & & & & & & & & Cohens d \\
\hline $\begin{array}{l}\text { WMS-R indices } \\
\text { General Memory }\end{array}$ & $\begin{array}{l}105.3 \\
(14.5)\end{array}$ & $\begin{array}{l}99.5 \\
(17.5)\end{array}$ & $\begin{array}{l}89.2 \\
(13.4)\end{array}$ & $\begin{array}{l}101.5 \\
(20.3)\end{array}$ & $\mathrm{F}=3.8$ & $0.013^{*}$ & $\begin{array}{l}\text { LT better } \\
\text { than AI }\end{array}$ & $\begin{array}{l}1.15(\mathrm{CI} \\
0.51-1.79)\end{array}$ \\
\hline $\begin{array}{l}\text { WMS-R indices } \\
\text { Verbal memory }\end{array}$ & $\begin{array}{l}101.1 \\
(16.7)\end{array}$ & $\begin{array}{l}95 \\
(19.4)\end{array}$ & $\begin{array}{l}84.3 \\
(18)\end{array}$ & $\begin{array}{l}92.3 \\
(21.5)\end{array}$ & $\mathrm{F}=3$ & $0.037^{\mathrm{d}}$ & $\begin{array}{l}\text { LT better } \\
\text { than AI }\end{array}$ & $\begin{array}{l}0.97(\mathrm{CI} \\
0.33-1.6)\end{array}$ \\
\hline $\begin{array}{l}\text { WMS-R indices } \\
\text { Visual Memory }\end{array}$ & $\begin{array}{l}108.9 \\
(10.9)\end{array}$ & $\begin{array}{l}105.4 \\
(14.4)\end{array}$ & $\begin{array}{l}100.4 \\
(11.7)\end{array}$ & $\begin{array}{l}108.5 \\
(13.9)\end{array}$ & $\mathrm{F}=2$ & 0.126 & & \\
\hline $\begin{array}{l}\text { ROCF (delay) pt } \\
\text { Visual Memory }\end{array}$ & $\begin{array}{l}17.0 \\
(6.4)\end{array}$ & $\begin{array}{l}17.9 \\
(7.6)\end{array}$ & $\begin{array}{l}14.5 \\
(6.3)\end{array}$ & $\begin{array}{l}13.9 \\
(4.2)\end{array}$ & $\mathrm{F}=1.7$ & 0.2 & & \\
\hline \multicolumn{9}{|l|}{ Visuoconstruction $^{\mathrm{b}}$} \\
\hline ROCF (copy) pt. rank ${ }^{c}$ & 45.3 & 43.4 & 28.6 & 47.0 & $\chi^{\mathrm{b}}=8.5$ & $(0.037)$ & $\begin{array}{l}\text { (all better } \\
\text { than AI) }\end{array}$ & nd \\
\hline \multicolumn{9}{|l|}{ Attention $^{\mathrm{b}}$} \\
\hline $\begin{array}{l}\text { WMS-R indices } \\
\text { Attention }\end{array}$ & $\begin{array}{l}90.1 \\
(17.5)\end{array}$ & $\begin{array}{l}98.5 \\
(16.3)\end{array}$ & $\begin{array}{l}88.7 \\
(14)\end{array}$ & $\begin{array}{l}99.9 \\
(10.3)\end{array}$ & $\mathrm{F}=2.77$ & $(0.047)$ & $\begin{array}{l}\text { (TAM better } \\
\text { than AI } \\
\text { SWITCH better } \\
\text { than AI) }\end{array}$ & nd \\
\hline $\begin{array}{l}\text { TMT A } \\
\text { Visual attention }\end{array}$ & $\begin{array}{l}39.1 \\
(10.4)\end{array}$ & $\begin{array}{l}33.9 \\
(10.4)\end{array}$ & $\begin{array}{l}41.6 \\
(14.5)\end{array}$ & $\begin{array}{l}35.5 \\
(8.7)\end{array}$ & $\mathrm{F}=1.97$ & $(0.13)$ & & \\
\hline \multicolumn{9}{|l|}{ Executive functioning ${ }^{\mathrm{b}}$} \\
\hline $\begin{array}{l}\text { TMT B } \\
\text { Task switching }\end{array}$ & $\begin{array}{l}90.1 \\
(17.5)\end{array}$ & $\begin{array}{l}98.5 \\
(16.3)\end{array}$ & $\begin{array}{l}88.7 \\
(14)\end{array}$ & $\begin{array}{l}99.9 \\
(10.3)\end{array}$ & $\mathrm{F}=2.77$ & $(0.59)$ & & \\
\hline
\end{tabular}

aplanned comparisons.

${ }^{\text {bExploratory. }}$

${ }^{\mathrm{c}}$ No normal distribution, thus ANOVA not possible, mean only for information.

${ }^{\mathrm{d} D i d}$ not remain significant after correction by false discover rate.

$\mathrm{LT}=$ local therapy group, $\mathrm{TAM}=$ tamoxifen, $\mathrm{AI}=$ aromatase inhibitor, SWITCH: TAM $\rightarrow \mathrm{AI}$, WSM-R $=$ Wechsler Memory Scale revised, $\mathrm{ROCF}=$ Rey-Osterrieth Complex Figure Test, $\mathrm{TMT}=$ Trail Making Test, $\mathrm{CI}=$ confidence interval, $\mathrm{SD}=$ standard deviation, $\mathrm{pt}=$ points, Cohens $\mathrm{d}=$ effect size, $\mathrm{nd}=$ not done. ${ }^{*} \mathrm{p}<0.05$.
Differences of age between the groups were not significant. Furthermore, compared scores were already age-adjusted indices. In addition, an ANCOVA was performed with the 4 treatment conditions as between-groups factor and age as the covariate. We did not find any effects of age with regard to memory (general memory: $\mathrm{p}=0.58$, verbal memory: $\mathrm{p}=0.29$, visual memory: $\mathrm{p}=0.92$ ). Group differences with regard to general memory remained significant $(\mathrm{p}=0.026)$

\section{Spatial Cognition (Planned Comparisons)}

No significant differences were seen with respect to navigation and mental rotation. The majority of participants showed low performances on this test. For the 3 learning trials and the test run of the Object in Location Task (navigation with landmarks), no significant mean differences in terms of time required, length of path, average deviation angle (average heading error) and success (treasure chest found) were detected. With regard to the Virtual Pointing Task (navigation without landmarks), we did not find any significant results when the results of all runs were averaged (table 4). An ANCOVA was performed with the 4 treatment conditions as the between-group factor and age as the covariate. We did not find significant effects of age on spatial cognition (Mental Rotation Test: strong $\mathrm{p}=0.34$, mild $\mathrm{p}=0.68$, Virtual Pointing Task: estimation error $\mathrm{p}=0.68$, orientation time $\mathrm{p}=0.51$, Object in Location Task: average heading error $\mathrm{p}=0.46$ ).

\section{Attention, Processing Speed and Visuoconstruction (Exploratory)}

The AI group performed worse than the TAM and the 'SWITCH' groups concerning attention (table 3). AI patients performed worse than the other groups concerning visuoconstruction. These results should be analyzed in more detail in further studies.

\section{Discussion}

The results of our study suggest that women who are completely estrogen deprived without any TAM treatment in the past achieved a significant lower mean in general memory compared to the control group. Considering the potentially protective effects of estro- 
Table 4. Results for spatial cognition

\begin{tabular}{|c|c|c|c|c|c|c|}
\hline & $\begin{array}{l}\mathrm{LT} \\
\mathrm{n}=21\end{array}$ & $\begin{array}{l}\text { TAM } \\
\mathrm{n}=22\end{array}$ & $\begin{array}{l}\mathrm{AI} \\
\mathrm{n}=22\end{array}$ & $\begin{array}{l}\text { SWITCH } \\
\mathrm{n}=15\end{array}$ & $\begin{array}{l}\text { Test } \\
\text { statistic }\end{array}$ & $\mathrm{p}$ \\
\hline \multicolumn{7}{|l|}{ Mental rotation test, mean (SD) } \\
\hline Total strict $(\max 24 \mathrm{pt})$ & $6.1(3.8)$ & $7.1(3.2)$ & $6.4(2.1)$ & $6.8(4.4)$ & $\mathrm{F}=0.32$ & 0.83 \\
\hline Total lenient $(\max 48 \mathrm{pt})$ & $21.4(5.6)$ & $23.5(6.5)$ & $24.4(4.4)$ & $23.9(6.0)$ & $\mathrm{F}=1.1$ & 0.81 \\
\hline \multicolumn{7}{|c|}{ Object in location task (navigation with landmarks) } \\
\hline Mean time, $s$ & 36.8 & 38.1 & 43.1 & 45.4 & $\chi^{2}=1.7$ & 0.63 \\
\hline Length of path ${ }^{\mathrm{a}}$ & 32.8 & 41.0 & 46.3 & 42.0 & $\chi^{2}=3.75$ & 0.29 \\
\hline $\begin{array}{l}\text { Average heading error in }{ }^{\circ} \\
\text { mean (SD) }\end{array}$ & $48.7(14.6)$ & $52(14.5)$ & $59.0(15.3)$ & $55.2(15.2)$ & $\mathrm{F}=1.8$ & 0.15 \\
\hline Number of detected treasure chests ${ }^{\mathrm{a}}$ & 42.3 & 42.4 & 42.2 & 32.7 & $\chi^{2}=5.9$ & 0.12 \\
\hline \multicolumn{7}{|l|}{ Path integration, mean (SD) } \\
\hline $\begin{array}{l}\text { Navigation time, } s \\
\text { Runs } 1-3 \text {, mean summarized }\end{array}$ & $\begin{array}{l}28,732 \\
(11,319)\end{array}$ & $\begin{array}{l}19,997 \\
(6,209)\end{array}$ & $\begin{array}{l}24,756 \\
(12,338)\end{array}$ & $\begin{array}{l}23,407 \\
(12,010)\end{array}$ & 2.47 & 0.069 \\
\hline $\begin{array}{l}\text { Estimation error }{ }^{\mathrm{b}} \text { in } \\
\text { Runs } 1-3, \text { mean summarized }\end{array}$ & $11.7(4.1)$ & $10.9(3.6)$ & $12.0(3.2)$ & $9.9(2.5)$ & 1.36 & 0.26 \\
\hline
\end{tabular}

${ }^{a}$ No normal distribution, rank

${ }^{\mathrm{b}}$ Difference from real and estimated angle divided by 6 .

$\mathrm{LT}=$ local therapy, $\mathrm{TAM}=$ Tamoxifen, $\mathrm{AI}=$ aromatase inhibitor, $\mathrm{SWITCH}=\mathrm{TAM} \rightarrow \mathrm{AI}, \mathrm{SD}=$ standard deviation, $\mathrm{pt}=$ points. ${ }^{*} \mathrm{p}<0.05$. gens on CNS function, these findings seem to be consistent. However, with regard to spatial cognition, we generally did not find significant results when subtests were summarized.

Overall, no differences were observed between the 'SWITCH' and the TAM group in our study. The results may be limited by the fact that patients in the 'SWITCH group' had previously received more HT for postmenopausal symptoms before the diagnosis of breast cancer than patients in the other groups. The extent to which previous HT has an impact on patient performance is unknown. Some previous studies concluded that healthy women who had received HT in the past, but not at the time of assessment, achieved better cognitive performances than the control group [30,31]. The effect of a previous HT on cognition should be clarified in further studies.

Similar results concerning endocrine therapy and cognition were shown by Bender et al. [32, 33] and Collins et al. [34], who also found deterioration of cognition under AI treatment. However, Philips et al. [35] and Jenkins et al. [36] showed conflicting results. Phillips et al. [35] noticed that the AI group performed significantly better than the TAM group when a composite score was calculated, but both groups performed below age norms in most domains. Jenkins et al. [36] ascertained in their prevention study that there were no statistically significant differences in cognitive function between the AI group and the placebo group at any time point.

One of the advantages of our study is the separation of the different options of endocrine therapy in each treatment group. All women were postmenopausal. The groups were statistically parallel, apart from history of HT in the past. A comprehensive assessment of spatial cognitive ability was not performed in previous studies. In addition, confounders such as chemotherapy were excluded, even if the magnitude of the impact of chemotherapy is still controversial $[17,37]$. In a meta-analysis of 17 studies on chemotherapy-induced cognitive impairment in patients with breast can- cer, Jim et al. [38] reported an impairment of verbal and visuospatial ability compared to healthy controls.

One major limitation of this study was the cross-sectional design. Measurement occurred at 1 time point only, and the results provide no information about the sequence of the events, e.g. we do not know whether patients were already impaired before onset of treatment. Another limitation may be seen in the number of measured data, which necessitated adjusting $\mathrm{p}$ values. This involves the risk that potential differences remain undetected. Generally, a differentiation between patients receiving chemotherapy and endocrine therapy is essential, because chemotherapy is a potential confounder [37, 38]. Different types of endocrine therapy - antiestrogens and AIs - should be studied separately. In addition, the steroidal AI exemestane with its androgenic properties could show an advantage in cognitive functioning when compared with TAM or non-steroidal AIs such as anastrozole and letrozole [39]. Moreover, the time interval since menopause may have an effect on cognitive functioning. It is conceivable that women who have been postmenopausal for many years may tolerate a complete estrogen deprivation better than those who are barely postmenopausal. Against this background, it was remarkable to find significant results even though AI patients were on average 15 years postmenopausal. Further studies should clarify whether a shorter period since menopause would modify the cognitive effects of AIs. Furthermore, body weight may play a role in endocrine therapy. It is not known whether obese women are subject to complete estrogen suppression with AIs. Different results have been found in various studies [40-42]. In TAM treatment, the level of the active metabolites may have impact on effects and side effects including cognitive impairment. Therefore, poor metabolizers, e.g. due to CYP2D6 polymorphisms, should be studied separately from normal metabolizers. Another important factor is reduced compliance for endo- 
crine therapy in patients with breast cancer. A number of studies have shown different discontinuation rates [43-45]. Highest discontinuation rates of $49.7 \%$ were found by Fontein et al. [45] in the first 6 months of treatment. Although compliance was assessed in the pre-test interview, in planning future studies we suggest assessing compliance pharmacologically (by drug level measurement) to gain a better estimate of the true impact of endocrine therapy.

In conclusion, adverse effects on cognitive function through adjuvant endocrine treatment can frequently be detected and may be of clinical relevance. These side effects may influence patient coun- selling with regard to AI use for adjuvant treatment in early breast cancer, e.g. by preferring shorter over longer AI treatment periods. In the future, prospective trials with larger samples will be necessary to elucidate this observation further. However, adjustment for potential confounders is important.

\section{Disclosure Statement}

The authors indicated no potential conflicts of interest.

\section{References}

1 Sherwin BB, Henry JF: Brain aging modulates the neuroprotective effects of estrogen on selective aspects of cognition in women: A critical review. Front Neuroendocrinol 2008;29:88-113.

2 Stelly CE, Cronin J, Daniel JM, Schrader L: Long-term oestradiol treatment enhances hippocampal synaptic plasticity that is dependent on muscarinic acetylcholine receptors in ovariectomised female rats. J Neuroendocrinol 2012;24:887-896.

3 Foy MR: 17beta-estradiol: Effect on CA1 hippocampal synaptic plasticity. Neurobiol Learn Mem 2001;76: 239-252.

4 Hara Y, Waters EM, McEwen BS, Morrison JH: Estrogen effects on cognitive and synaptic health over the lifecourse. Physiol Rev 2015;95:785-807.

5 Riecher-Rössler A: Psychoprotektive Effekte von Östrogenen. J Neurol Neurochir Psychiatr 2011;12:152156.

6 Gazzaley AH, Weiland NG, McEwen BS, Morrison JH: Differential regulation of NMDAR1 mRNA and protein by estradiol in the rat hippocampus. J Neurosci 1996; 16:6830-6838.

7 Rao ML, Kölsch H: Einfluss von Östradiol-17 $\beta$ auf die Hirnentwicklung und seine Eigenschaften als Neuroprotektivum. J Neurol Neurochir Psychiatr 2002;3:3439.

$\checkmark 8$ Azcoitia I, Sierra A, Veiga S, et al.: Brain aromatase is neuroprotective. J Neurobiol 2001;47:318-329.

7 Arevalo AM, Azcoitia I, Garcia-Segura LM: The neuroprotective actions of oestradiol and oestrogen receptors. Nat Rev Neurosci 2015;16:17-29.

10 McEwen BS, Akama KT, Spencer-Segal JL, et al.: Estrogen effects on the brain: actions beyond the hypothalamus via novel mechanisms. Behav Neurosci 2012;126: 4-16.

11 Resnick SM, Espeland MA, An Y, et al.: Effects of conjugated equine estrogens on cognition and affect in postmenopausal women with prior hysterectomy. J Clin Endocrinol Metab 2009;94:4152-4161.

12 Chabanne V, Péruch P, Thinus-Blanc C: Sex differences and women's hormonal cycle effects on spatial performance in a virtual environment navigation task. Curr Psychol Cognition 2005;22:351-375.

13 Kok HS, Kuh D, Cooper R, et al.: Cognitive function across the life course and the menopausal transition in a British birth cohort. Menopause 2006;13:19-27.

14 Hausmann M, Slabbekoorn D, van Goozen SH, et al. Sex hormones affect spatial abilities during the menstrual cycle. Behav Neurosci 2010;14:1245-1250.

15 Massarweh S, Osborne CK, Dipietro M, et al.: Tamoxifen's agonist effect on breast cancer growth is mediated by activation of EGFR/HER-2 with preservation of its antagonist effect on ER-dependent gene expression. ASCO Annual Meeting Proceedings (Post-Meeting Edition). J Clin Oncol 2004;22(Suppl 14):541.
6 Brodie AM, Njar VC: Aromatase inhibitors and their application in breast cancer treatment. Steroid 2000; 65:171-179.

17 Vodermaier A: Breast cancer treatment and cognitive function: The current state of evidence, underlying mechanisms and potential treatments. Womens Health (Lond Engl) 2009;5:503-516.

18 Duarte-Guterman P, Yagi S, Chow C, Galea LA: Hippocampal learning, memory, and neurogenesis: Effects of sex and estrogens across the lifespan in adults. Horm Behav 2015;74:37-52.

19 Winterling D, Crook T, Salama M, Gobert J: A selfrating scale for assessing memory loss, in Bes $\mathrm{A}$, Cahn J, Hoyer S, et al.: (eds), Senile dementia: Early detection. London, John Libbey Eurotext, 1986, pp 482-486.

20 von Zerssen D: Die Befindlichkeitsskala (Bf-S') - Manual Beltz Test. Weinheim, 1976.

21 Zigmond AS, Snaith RP: The hospital anxiety and depression scale. Acta Psychiatr Scand 1983;67:361-370.

22 Fischer B: Multiple choice vocabulary test MWT as a valid and short test to estimate premorbid intelligence. Acta Neurol Scand1995;91:335-345.

23 Reitan RM: Trail Making Test: Manual for administration and scoring. Reitan Neuropsychology Laboratory, South Tucson, AZ, 1992.

24 Härting C, Markowitsch HJ, Neufeld H, et al.: Wechsler Memory Scale - Revised Edition, German Edition. Manual. Bern: Huber. 2000.

25 Osterrieth PA: The Complex Figure Copy Test. Arch Psychol 1994;30:206-353.

26 Shepard R, Metzler J: Mental rotation of three dimensional objects. Science 1971;171:701-703.

27 Schönfeld R, Lehmann W, Leplow B: Effects of age and sex in mental rotation and spatial learning from virtual environments. J Individ Differ 2010;31:78-82.

28 Schönfeld R, Mönich N, Müller FJ, et al.: Search strategies in a human water maze analogue analyzed with automatic classification methods. Behav Brain Res 2010;208:169-177.

29 Benjamini Y, Hochberg Y: Controlling the false discovery rate: A practical and powerful approach to multiple testing. J R Stat Soc Ser B 1995;57:289-300.

30 Matthews K, Cauley J, Yaffe K, Zmuda JM: Estrogen replacement therapy and cognitive decline in older community women. Am Geriatr Soc 1999;47:518-522.

31 Zandi PP, Carlson MC, Plassman BL, et al.: Hormone replacement therapy and incidence of Alzheimer disease in older women: The Cache County Study. JAMA 2002;288:2123-2129.

32 Bender CM, Sereika SM, Brufsky AM, et al.: Memory impairments with adjuvant anastrozole versus tamoxifen in women with early-stage breast cancer. Menopause 2007;14:995-998.

33 Bender CM, Merriman JD, Gentry AL, et al.: Patterns of change in cognitive function with anastrozole therapy. Cancer 2015;121:2627-2636.
4 Collins B, Mackenzie J, Stewart A, et al.: Cognitive effects of hormonal therapy in early stage breast cancer patients: A prospective study. Psychooncology 2009; 18:811-821.

35 Phillips KA, Ribi K, Sun Z, et al.: Cognitive function in postmenopausal women receiving adjuvant letrozole or tamoxifen for breast cancer in the BIG 1-98 randomized trial. J Breast 2010;19:388-395.

36 Jenkins VA, Ambroisine LM, Atkins L, et al.: Effects of anastrozole on cognitive performance in postmenopausal women: A randomised, double-blind chemoprevention trial (IBIS II). Lancet Oncol 2008;9:953-961.

37 Ono M, Ogilvie JM, Wilson JS, et al.: A meta-analysis of cognitive impairment and decline associated with adjuvant chemotherapy in women with breast cancer. Front Oncol 2015;5:59.

38 Jim HS, Phillips KM, Chait S, et al.: Meta-analysis of cognitive functioning in breast cancer survivors previously treated with standard-dose. J Clin Oncol 2012; 30:3578-3587.

39 Schilder CM, Seynaeve C, Beex LV, et al.: Effects of tamoxifen and exemestane on cognitive functioning of postmenopausal patients with breast cancer: Results from the neuropsychological side study of the tamoxifen and exemestane adjuvant multinational trial. J Clin Oncol 2010;28:1294-1300.

40 Sestak I, Distler W, Forbes JF, et al.: Effect of body mass index on recurrences in tamoxifen and anastrozole treated women: An exploratory analysis from the ATAC trial. J Clin Oncol 2010;28:3411-3415.

41 Pfeiler G, Königsberg R, Fesl C, et al.: Impact of body mass index on the efficacy of endocrine therapy in premenopausal patients with breast cancer: An analysis of the prospective ABCSG-12 trial. J Clin Oncol 2011;29: 2653-2659.

42 Egle D, Oberguggenberger A, Achleitner R, et al.: Do obese women benefit less from adjuvant endocrine therapy with aromatase inhibitors? Preliminary analysis on the association of BMI and aromatase inhibitor plasma levels. ASCO Meeting May 20, Abstracts. 2011; 29(15 Suppl).

43 Hadji PV, Ziller V, Holzhauer W, et al.: Compliance with tamoxifen and arimidex in the adjuvant treatment of women with breast cancer. Breast Cancer Res Treat 2007;106:146-150.

44 Fasching PA, Fehm T, Kellner S, et al.: Evaluation of therapy management and patient compliance in postmenopausal patients with hormone receptor-positive breast cancer receiving letrozole treatment: The Evaluate TM Study. Geburtshilfe Frauenheilkd 2014;74: 1137-1143.

45 Fontein DB, Nortier JW, Liefers GJ, et al.: High noncompliance in the use of letrozole after 2.5 years of extended adjuvant endocrine therapy. Results from the IDEAL randomized trial. Eur J Surg Oncol 2012;38: 110-117. 